\title{
An analytical Perspective on the Fellowship Narrative OF GENESIS 18:1-15
}

\author{
Authors: \\ Ahn Sang Keun ${ }^{1}$ \\ Pieter M. Venter

\section{Affiliation: \\ ${ }^{1}$ Department of Old \\ Testament Studies, \\ University of Pretoria, \\ South Africa}

\section{Correspondence to:}

Pieter Venter

email:

pm.venter@up.ac.za

\section{Postal address:}

PO Box 914-1530, Wingate

Park 0153, South Africa

\section{Keywords:}

Abraham; Fellowship

Narrative; Genesis 18:1-5;

narrative criticism; plot

sequence; sandwiched

structure

\section{Dates:}

Received: 26 Nov. 2009

Accepted: 07 Apr. 2010

Published: 23 Aug. 2010

How to cite this article: Keun, A-S. \& Venter, P.M., 2010, 'An analytical perspective on the Fellowship Narrative of Genesis 18:1-15', HTS Teologiese Studies/ Theological Studies 66(1), Art. \#773, 8 pages. DOI: 10.4102/hts.v66i1.773

\section{This article is available} at:

http://www.hts.org.za

\section{Note:}

This article is a reworked version of a section of the PhD dissertation 'A study of God's encounter with Abraham in Genesis $18^{\prime}$ by Ahn Sang Keun, completed in 2009 under the supervision of Prof. Dr Pieter M. Venter of the Department of Old Testament Studies in the Faculty of Theology at the University of Pretoria.

(c) 2010. The Authors. Licensee: OpenJournals Publishing. This work is licensed under the Creative Commons Attribution License.

\section{ABSTRACT}

The narrative in Genesis 18:1-15 deals with God's visit to Abraham at Mamre. The general tendency in the interpretation of this narrative is to focus on Abraham's hospitality. It is usually interpreted as an example of his righteousness, in line with Hebrews 13:2, or with the test motive of the Greek myth of the birth of Orion. These interpretations, however, seem to be in conflict with the narrator's own theological views.

This study, therefore, attempts to explore the view point of the author of the Fellowship Narrative (Gn 18:1-15) within the context of the larger Abraham narrative (Gn 11:27-25:11). The method used for the investigation is mainly that of narrative criticism. Attention is paid to the narrator's various literary skills: 'linking structure with preceding episode' (Gn 18:1a), the 'sandwiched structure' of the larger context (Gn 18:1-21:7), the unique plot sequence, as well as repeated clue words and phrases (such as 'laugh', 'Sarah' and 'this time next year'). These literary aspects are used by the narrator to depict the faithfulness of the Lord who fulfils what he promised. The conclusion of this study overturns the traditional interpretations of the Fellowship Narrative.

\section{INTRODUCTION}

The traditional interpretation of the narrative in Genesis 18:1-15 underlines Abraham's hospitality and links it to his later recognition of the deity (cf. Ambrose, Augustine, Brueggemann 1997:166; Calvin 1992:468; Exell 1900:5; Gunkel 1997:193; Hamilton 1995b:9; Hartley 2000:177; Oden 2002:62-64; Ross 1988:338; Simpson 1978:616-617; Wenham 1994:45). According to this interpretation, the purpose of the Lord's visit in human form was to test Abraham's hospitality. Therefore, they assert that Abraham could not recognise the deity at the initial moment of their encounter (cf. Gunkel 1997:193). They therefore praise Abraham's hospitable manner and interpret Abraham's receiving the promised son as the reward for his hospitality during this occasion (cf. Wenham 1994:45). However, this cannot be the case, as Isaac's birth was already announced in the previous episode (cf. Gn 17:19, 21) without Abraham's proof of his hospitality.

On the other hand, there are a few scholars who have an alternative viewpoint. They uphold the position of Abraham's immediate recognition of the divinity of his visitors. According to this view, the purpose of God's visit was to share covenantal fellowship with Abraham and his household (cf. Ross 1988:343; Sailhamer 1990). Receiving Isaac was the result of the Lord's covenantal faithfulness who keeps his promise, not the reward for Abraham's hospitality (Gn 17:17; 18:13, 15; cf. Ross 1988:345-346; Sailhamer 1990:148).

Different interpretative perspectives affect the outcome of the investigation of this narrative in different ways. This study attempts to find the meaning of this episode by using the method of narrative criticism (cf. Simpson 1978:137; Westermann 1985:274). This study assumes that the view that Abraham immediately recognised his visitors, is the author's own interpretative perspective as he presented it in the Fellowship Narrative (Gn 18:1-15). Consequently this study will try to attest that God's courteous visit to Abraham did not have any test motive as held by traditional scholars, but, rather, its purpose was to share covenantal fellowship with him. To do this, the author's narrative skills used within the larger context of the narrative (Gn 11:27-25:11) are investigated, as an analysis of this nature might help to indicate the theological meaning of this episode in Genesis 18:1-15.

\section{GENRE OF GENESIS 18:1-15}

Categorically the text of Genesis 18:1-15 belongs to the patriarchal narratives (cf. Coats 1983:102; Gunkel 1994:13; Hartley 1995:130-232; Mathews 1996:104-328; Roop 1987:93-161; Sailhamer 1976:108-181). As a narrative, it consists of the three basic narrative elements: space, time, character, as well as a fourth element plot (cf. Block 1999:601; Knight 2004:171; Venter 2005:5). Furthermore, this episode applies the literary genre of a comic plot, for it shows the markings of a happy-ending story (Gn 18:10, 14; cf. Gn 17:21; Hartley 1995:178; Sarna 1989a:128, 130). The physical condition of the protagonists was that they were too old to raise any children, so that when the Lord presents a word of annunciation to the couple, they laugh sceptically (Gn 17:17; 18:12). However, by the divine intervention they will laugh in the end out of joy (Gn 21:1-7; cf. Mathews 1996:216)

In the end, the story deals with the coming birth of a child. It can, therefore, be titled 'Annunciation Narrative' (Gn 18:9-15; cf. Coats 1983:137; Wenham 1994:40). However, within the whole Abraham narrative (Gn 12:1-25:11), the annunciation about the offspring has been repeated many times (Gn 13:16; 15:5; 17:19). Thus, the title 'Annunciation Narrative' does not seem to express the uniqueness of this narrative.

The narrative in Genesis18:1-15 is of exceptional significance. Here the Lord initially appears as three men, which is quite unique in the Old Testament (cf. Von Rad 1972:205). Heavenly visitors here eat 
meals like human beings do, which is also a unique act of the divine beings (Gn 18:1-8). They pay direct attention to Sarah for the first time in her life in this episode (Gn 18:9-15). In this unique way, the narrator tells his story in a dramatic fashion that highlights God's special relationship with his beloved covenant partners (cf. Hamilton 1995b:17; Ross 1988:343; Sailhamer 1976:144).

Therefore, the title of this episode rather needs to be called 'The Fellowship Narrative'. The narration of these significant elements is much more symbolic in nature than an objective representation of the event (Coats 1983:102). This narrative draws the attention of the readers to understanding both the Lord's eating and his special care for an old woman's unusual conception from a theological viewpoint.

\section{NARRATIVE STYLE}

According to literary criticism, the passage of Genesis 18:1-15 is identified as a naïve anthropomorphic, theophany narrative by the J editor ${ }^{1}$, who uses a picturesque, lucid and flexible style of description to form a major component in the Abraham-Lot legend cycle (cf. Driver 1904:191; Gunkel 1997:192; Skinner 1980:298). The progression of events in the narrative is written in the typical Hebrew narrative style, that is, the narrative style of this episode, especially when depicting the identity of the visitors, is paratactic. It is typified by an economy of detail about the moment of recognition of the deity, so that it seems to remain in obscurity (cf. Hamilton 1995b:7). The feelings and thoughts of Abraham are not so much externalised, as internalised through the narrative itself (Gen 18:9-15).

The description about the motive of God's appearance in human form seems to be lacking and the purpose of his visit seems to remain unexpressed (cf. Lundbom 1998:136-138) Readers, however, are drawn to the author's sophisticated skill to present the narrative as a tightly structured one, rather than just a loose and unskilful presentation of patriarchal cycles (cf. Wikipedia 2009). Therefore, the underlying theological motif has to be explored by means of analysing the interaction between narrative materials and the underlying plot structure (cf. Venter 2005:3-4).

\section{THE STRUCTURAL ANALYSIS AND ITS INTERPRETATION}

The structure of the Fellowship Narrative (Gn 18:1-15) seems to be quite simple and clear (cf. Mathews 1996:215). It consists of the chapter heading (Gn 18:1a) followed by two scenes of equal length: Abraham welcomes the three visitors in a cordial manner (1st scene; Gn 18:1b-8) and then Abraham receives a word of encouraging reconfirmation for Sarah's conception in a dialogue form (2nd scene; Gn 18:9-15; Gunkel 1997:192; Hartley 1995:177). There is a fast movement from one significant action to the other and a quick progress in the dialogues including narrative remarks in the course of the narrative (cf. Westermann 1985:274)

Generally, the Fellowship Narrative (Gn 18:1-15) is known as the first section of the larger narrative complex of Genesis 18 and 19 (cf. Driver 1904:191; Hamilton 1995b:30; Hartley 1995:177. Von Rad 1972:204; Wenham 1994:40 -43; Westermann 1985:274). Traditional interpretations see a structural relationship of the Fellowship Narrative (Gn 18:1-15) with the following Sodom episode (Gn 18:16-19:38). That is why this narrative (Gn 18:115 ) is sometimes called 'the first section' of the larger narrative complex of Genesis 18 and 19.

Recently Mathews (1996:209) attempted to analyse the narrative from the perspective of the progeny theme and, as such, he

1.According to literary criticism the source for this passage was a compiler of oral traditions known as the 'Yahwist', because of his frequent use of the name Yahwe for God. divided the narrative complex (Gn 18-19) into the following subsections, finding a chiasmus between them:

- A - Genesis 18:1-15: Visitors' announcement of Isaac's birth.

- B - Genesis 18:16-19:29: Annunciation and Destruction of Sodom.

- $\quad \mathrm{A}^{\prime}$ - Genesis 19:30-38: Birth of Lot's sons Moab and BenAmmi.

Even though Mathews used a method of narrative criticism, he considered the structural connection with the following Sodom narrative one-sidedly, as traditional scholars have done. However, if one reads the first section in the Hebrew Scripture, one may find that the structure of the first section (Gn 18:1-15) is closely linked with the preceding episode (Gn 17:23-27), as can be seen in the syntactical function of the opening phrase, (וירא אליו יהוה) 'the Lord appeared to him' (LXE, KJV; Gn 18:1a). Syntactically, the antecedent of 'him' is Abraham as referred to in the previous episode, Genesis 17:26 (cf. Sailhamer 1976:142).

However, the NIV and NIB translations might mislead readers to misunderstand the linking structure, for these translate it into 'the Lord appeared to Abraham' instead of 'the Lord appeared to him'. The translations of the NIV and NIB thus obscure the significant linking structure, which could mislead readers because this linking structure seems to direct readers to understand the episode of the Fellowship Narrative in light of the preceding event (cf. Sailhamer 1976:142; Von Rad 1972:204). This study considers the structural relationship between the preceding episode and the following one. As such, it is necessary to attempt to seek a new interpretative perspective from this linking structure.

If one considered that this episode (Gn 18:1-15) belongs to the sequence of the traditional annunciation narratives (cf. $1 \mathrm{Sm}$ 1:1-20; 2 Ki 4:8-17; Hamilton 1976:72-74; Hasel 1998:181-182; Mathews 1996:265-267; Wenham 1987:273), one may find that it is incomplete in terms of the form usually defined in these narratives (cf. Coats 1983:138). There is no fulfilment part here that reports giving birth to a child. Readers find it only later in the passage of Genesis 21:1-7 after several episodes have been inserted (Gn 18:16-20:18). Therefore, an extended larger structural context has to be considered (Gn 18:1-21:7) as it seems as if the narrator tried to insert some additional messages into this structural context. This 'sandwiched structure' will be addressed later in this paper.

\section{PROBLEM OF THE TRADITIONAL STRUCTURAL INTERPRETATION}

Traditionally, the first section (Gn 18:1-15) of the Hebron narrative has been interpreted in tandem with the Sodom narrative (Gn 19:1-38; cf. Calvin 1963:495-496; Driver 1904:198; Hamilton 1995b:33; Mathews 1996:213; Oden 2002:63; Von Rad 1972:217-218; Westermann 1985:274, 302). Thematically the episode of the first section (Gn 18:1-15), however, stands in contrast to the tragic development of the Sodom story (cf. Mathews 1996:208). Scholars have been interested in comparing the different numbers of visitors, the spirituality of the hosts, the nuance of geographical and time setting, the response of the visitors to the invitation of the host and the result of hospitality between these two sections (cf. Hartley 1995:177; Skinner 1980:306). Consequently, through this kind of contrast, the general tendency in the interpretation of this first episode (Gn 18:1-15) was to focus on the exemplary acts of Abraham's hospitality (cf. Mathews 1996:213).

The result was that readers were asked to pay attention only to the importance of meritorious works (ethical sense of righteousness) conducted by human beings for the purpose of receiving a reward of salvation (cf. Wenham 1994:45; cf. also Gunkel 1997:192; Skinner 1980:302-303; Von Rad 1972:205). Readers may find some better examples of sound behaviour 
when Abraham's camp is compared to Lot's dwelling in the city. However, such an interpretative perspective seems to collide with the author's theological view on righteousness and deliverance (Gn 15:6; 19:29; 21:1). The problem of such an interpretative perspective is that it ignores God's demonstration of faithfulness in the keeping of his promise for his covenant partners in the second scene (Gn 18:9-15; cf. Mathews 1996:122; Tenney 1977).

Recent scholars find that the Fellowship Narrative (Gn 18:1-15) functions as the first section of a sandwiched structure in the macro context (Gn 18:1-21:7) covering the promise part to the fulfilment part (cf. Mathews 1996:246; Ross 1988:340; Wenham 1994:75; Westermann 1985:274). By using this structure, the author seems to indicate the Lord's special favour for his covenant partners in keeping to what he promised.

\section{SANDWICHED STRUCTURE IN THE LARGER CONTEXT (GN 18:1-21:7)}

According to the common structural pattern usually found in narratives of barren matriarchs in the Old Testament (Gn 25:19-26; 30:1-24; Jdg 13; 1 Sm 1:1-20; 2 Ki 4:8-17), the fulfilment part (i.e. the birth of the promised child) is always included (cf. Hamilton 1976:72-74; Hasel 1998:181-182; Mathews 1996:265267; Wenham 1987:273). In the Fellowship Narrative (Gn 18:115), however, the final fulfilment comes only later, in Genesis 21:1-7. The episodes of the Sodom tragedy (Gn 18:16-19:38) and the perilous abduction by King Abimelech of Abraham's wife (Gn 20:1-18) are inserted between the promise (Gn 18:915) and the fulfilment (Gn 21:1-7; cf. Mathews 1996:246; Ross 1988:340; Wenham 1994:75; Westermann 1985:274). In other words, structurally, two perilous events (Gn 18:16-20:18) are sandwiched in between the heading (Gn 18:1-15) and the closing parts (Gn 21:1-7). The macro structure shows that we are not dealing here with some loose collections of tales, but rather with a tightly structured one (cf. Wikipedia 2009).

This kind of literary skill can also be seen in the construction used for narrating Abram's early harsh experience (Gn 12:113:2) known as the first abduction of Sarai by Pharaoh (Gn 12:10-20; cf. Hartley 1995:140; Mathews 1996:246-247; Wenham 1994:68; Westermann 1985:161, 318). As soon as Abram received divine blessing there, he had to face the harsh and hostile reality of the present (Gn 12:1-13:1; cf. Sarna 1989a:93, 97). The event of Abram's sojourn into Egypt serves as an interlude (i.e. the 'sandwiched part') and is set between the promises of blessing (Gn 12:1-3,7) and the acquisition of riches by the intervention of the Lord (Gn 12:17-13:2; cf. Mathews 1996:122). Abraham's early and later life stories may be compared as follows:

Abram's early harsh experience (Gn 12:1-13:2):

- the heading part (Abram received blessed promises; Gn 12:1-7)

- 'sandwiched part' (harsh experience of famine and the abduction of Sarai by Egyptian king; Gn 12:8-16)

- the fulfilment part (God's intervention to deliver Sarai and Abram became very rich at last (Gn 12:17-13:2).

Abraham's later harsh experience (Gn 18:9-21:7):

- the heading part (Abraham received reconfirmation of the promise; Gn 18:9-15)

- the 'sandwiched part' (harsh experiences of Sodom disaster (Gn 18:16-19:38), moving down to Gerar and the abduction of Sarah by Abimelech, King of Gerar (Gn 20:2)

- the fulfilment part (God's intervention to deliver Sarah (Gn 20:3-18) and Abraham became a father of Isaac at last (Gn 21:1-7).

It is also important to note that Isaac, himself, later relocates to Gerar because of famine and experiences very similar harsh experiences to those of his father, Abraham (cf. Gn 26:1-33; cf. Hartley 1995:140; Sarna 1989a:93). Therefore, the author's theological intent should be read in terms of this sandwiched macro-plot (i.e. the larger structure) of the Abraham narrative (Gn 18:1-21:7).

\section{THE AUTHOR'S THEOLOGICAL INTENT FOR USING A SANDWICHED PLOT STRUCTURE}

The main theological theme found in the sandwiched structure is that the chosen ones who received God's promise may fall in danger and face the threat of failing God's promise, but the Lord intervenes in the situations and fulfils his promise magnificently (cf. Sailhamer 1976:116). Even though God's chosen ones show human deficiencies or weaknesses, Yahweh still rescues them and fulfils his promises (cf. Gn 12:1-13:2; Hartley 1995:137; Mathews 1996:122; Sarna 1989a:93; Tenney 1977; Von Rad 1972:169; Westermann 1985:168).

These sandwiched plot episodes (Gn 12:1-13:2; 18-21) emphasise God's special favour for his covenant partners even when they fall into dangerous situations (cf. Mathews 1996:246; Ross 1988:340; Westermann 1985:274). The Lord's partiality for Abraham is apparent, even though Abraham is accused of poor morality by the pagan kings (cf. Roop 1987:103). In reverse, this may demonstrate an important lesson about God's administration over fulfilling his plan of salvation. The Lord chose Abraham, who was a weak person, not a perfect one, because he was not an ideal character such as those found in heroic tales (cf. Gn 11:27-32; Dt 7:7; 9:4-6; Ps 14:1-3; 53:1-3; Ec 7; 20; Hartley 1995:138; Wenham 1987:291).

Therefore, the Lord shows his mercifulness and patience in making Abraham a father of faith, the head of a new priest nation for the whole world (Gn 12:1-3; Dt 9:4-6). The story apparently shows that Abraham could not attain security by his own performance (i.e. his meritorious good behaviour), only God could save under such circumstances (cf. Dt 9:4-6; Wenham 1987:291). Such elements of the salvation story become the foundation of human hope for receiving salvation apart from meritorious works (cf. Dt 9:4-6; Gl 3:5; Heb 2:14-18; Hamilton 1976:387).

Thus, it is essential to interpret the Fellowship Narrative (Gn 18:1-15) within the context of the macro-plot (sandwiched) structure (Gn 18-21) because the meritorious view on how Abraham's hospitality earned him a word of reconfirmation on the promised son Isaac is not in line with the author's theological intent, as shown by this sandwiched structure.

\section{LINKING THE STRUCTURE OF GENESIS 18 WITH GENESIS 17}

As already stated, recent scholars have paid close attention to the structural link of Genesis 18 with Genesis 17 (cf. Hartley 1995:175; Mathews 1996:195; Sailhamer 1976:143; Sarna 1989a:128; Wenham 1994:41, 45). If the Fellowship Narrative (Gn 18:1-15) is linked to what had happened just a few days before the events described therein (Gn 17:17, 21, 24 and 18:10a, cf. Gn 21:5), then, the author's interrelated theological intension becomes clear (cf. Von Rad 1972:204).

The episode of Genesis 18:1-15 is built upon the preceding episode (cf. Calvin 1963:468; Ross 1988:341; Sarna 1989b:128; Wenham 1994:41). The order of these events is important because readers are expected to consider each new episode in the light of what has gone before (cf. Knight 2004:171). Each preceding incident is the natural cause of that which follows (cf. Gunkel 1994:50). The last use of the name 'Abraham' was found in the account of the circumcision (Gn 17:23-27; cf. Sailhamer 1976:143). Abraham performed the circumcision promptly and

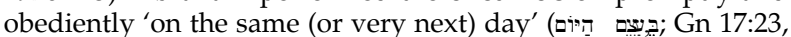
26), which is the very phrase repeated emphatically within the account of Genesis 17. 
Such a repeated phrase emphasises Abraham's revitalised faith and willing obedience (Gn 17:23a; 26; cf. Hartley 1995:175; Mathews 1996:207; Sailhamer 1976:142-143; Von Rad 1972:203). Acting faithfully to execute circumcision implies the subject of the preceding event (cf. Gn 17:23-27; Ross 1988:341; Sailhamer 1976:143; Sarna 1989b:128; Wenham 1994:41) and, therefore, the opening line of the Fellowship Narrative (Gn 18:1-15) must be understood as being closely linked to the preceding event $(\mathrm{Gn}$ 17:23-27), as indicated syntactically by the author. In this way, the author praises Abraham's swift obedience. Therefore, the phrase 'the Lord appeared to him', may be rephrased to read 'the Lord appeared to Abraham who finished the circumcision promptly out of revitalized faith' (cf. Hartley 1995:175; Knight 2004:171). The motive of the Lord's visit must, therefore, be understood as a well-wishing one.

Similar thematic elements found in both chapters (Gn 17; 18) also support such a linking view (cf. Hamilton 1995b:5; Sarna 1989b:128). These elements are predictions of the promised offspring (Gn 17:21; 18:10;14), the incredulous laughter of the covenant partners (Gn 17:16-21; 18:12-15) and the descriptions of the advanced age of the covenant partners (Gn 17:17-18 18:10-14; Mathews 1996:195). The chronological remarks on the ages of the main characters in both episodes (Gn 17:17, 21, 24 and 18:10a, 14, cf. Gn 21:5) also provide other evidence of the same structural link: 'Abraham was ninety-nine years old' (Gn 17:24), 'About this time next year' (Gn 18:10a) and 'A hundred years old when his son Isaac was born to him' (Gn 21:5). These chronological remarks usually indicate momentous occasions in the Pentateuch (Gn 7:13; Ex 12:17, 41, 51; Lv 23:21, 28-30; Dt 32:48; cf. Mathews 1996:207).

These common elements evidence the structural interdependence of Genesis 17 and 18 (cf. Mathews 1996:211; Sailhamer 1976:142).

\section{THEOLOGICAL MEANING OF THE PHRASE} 'THE LORD APPEARED TO'

The author of the book of Genesis uses the opening phrase 'the Lord appeared to', as distinct from divine speech usually introduced by $"$ " (va-yera); he uses it three times for Abraham (Gn 12:7; 17:1; 18:1), twice for Isaac (Gn 26:2, 24) and once for Jacob (Gn 35:1; 35:9; cf. Sarna 1989a:91). This opening phrase expresses the author's theological perspective (Gn 18:1; cf. Hamilton 1995b:7; Sailhamer 1976:142; Westermann 1985:277); the author usually indicates to the reader, by way of the opening phrases, the way in which the narrative that follows should be read (cf. Hartley 1995:177). This repeatedly used phrase is thus understood as carrying a specific theme (cf. Mathews 1996:216; Sarna 1989a:92; Westermann 1985:277). What great importance does the phrase 'the Lord appeared to' connote?

Firstly, the opening phrase 'the Lord appeared to' is used to indicate that the Lord visits covenant partners to give them a hopeful promise of both land and descendants (Gn 12:7; 17:1-8; 26:2-4; 35:9-13; Cassuto 1964:85-87; Mathews 1996:192-193 Wenham 1994:20). This phrase signals the well-wishing purpose of God's visit.

Secondly, there is no description about the covenant partners' terrified response to the theophany in the episodes narrated using the opening phrase 'the Lord appeared to' (cf. Bruegemann 1982:157). Commonly, the one encountering God in a theophany for the first time is afraid or terrified (cf. Gn 28:17; Ex 3:6; Jdg 6:2223; 13:22). In the Fellowship Narrative (Gn 18:1-15), Abraham is not terrified, for he already had experienced theophanic events many times before. The Chronicler describes Abraham as a friend of the Lord (2 Chr 20:7). Therefore, the opening phrase signals that the Lord is showing intimacy with his beloved ones (cf. Gn 35:9; Mathews 1996:192-193).

Thirdly, in the episodes initiated with the deity's title 'the Lord', God always appears to encourage his beloved servant by saying: 'Do not be afraid, Abram. I am your shield' (Gn 15:1), 'I will be with you' (Gn 26:3), 'I am with you', 'I will not leave you' (Gn 28:15). These encouraging and comforting words match well with the meaning of Yahweh ('One who is present', or 'One who is') that connotes 'Active Being', 'Present One', and 'Existing One' (cf. Ex 3:13-22; Brown 1979; Durham 1987:39). The Lord delivers his covenant partners, who are in some kinds of crisis, by granting them his personal presence (Gn 17:1, 17-18; 26:1-3, 28:13-15; 35:1-9; cf. Keil 1996:75-76; Ross 1988:341; Wenham 1994:222). In those cases, the phrase 'the Lord appeared to' signals his comfort and encouragement for his covenant partners.

Fourthly, the opening phrase signals the vivid revelation of the Lord. The Nifal form of the verb $ר(r a-a)$ is a technical term for divine self-disclosure meaning, 'to reveal oneself', 'to be seen' and 'make oneself visible' (cf. Brown 1979; Harris 1980; Sarna 1989b:92; VanGemeren 1997:1007-1014). Therefore, the theophanic verb ויר ('appeared') in the opening phrase ('the Lord appeared to') may be interpreted as 'he revealed himself visibly'; cf. Sarna 1989b:91; Van Gemeren 1997:1007). This is one of the textual proofs of Abraham's immediate recognition of the deity from the first moment.

Gradually, the Lord's methods of communication with Abram seem to have shifted from a simple method (Gn 12:1-3; 13:14-17) to a more profound way that was accompanied by visions and deep sleep (Gn 15:1, 12; cf. Hamilton 1976:377, 418). The author seems to heighten (or augment) its dramatic force by this shift, so that readers may notice that a divine intervention has occurred more vividly and even visibly as 'the Lord appeared to Abraham' when he obeyed faithfully to the Lord's command for the first time (cf. Gn 12:7; Hamilton 1976:377, 479; Mathews 1996:216, 207; Westermann 1985:155, 270).

Fifthly, in the events that followed the opening phrase, the Lord grants Abraham the opportunity to participate in his divine council through dialogue and to beg for the deliverance of other peoples (cf. Gn 18:16-33; cf. 2 Chr 20:7; Mathews 1996:222). These activities are understood as the fulfilment of Abraham's blessed role for all nations, which was promised to Abram when he was called by the Lord (cf. Gn 12:3; 18:19; Von Rad 1972:210).

One may conclude that Abraham is represented by this formula as someone who is greater than just an ordinary prophet. Abraham, who is honoured as God's friend, is a fitting prototype for the great prophets like Moses (cf. Gn 18:17; 2 Chr 20:7; Boice 1985:146-149; Mathews 1996:222). Thus, the opening phrase 'the Lord appeared to him' signals the blessed things in the following content of each episode of the narrative. The phrase also reminds readers of Abraham's preceding faithful acts of obedience to the Lord's command (Gn 12:4-6; 17:23-27).

On the other hand, other anthropomorphic parallels show some contrasting nuances in the use of the opening phrase 'the angel of the Lord' instead of 'the Lord appeared to'. Different usages of the divine title seem to signal different nuances of the narratives and further intertextual research on the use of opening phrases in relation to different divine titles is required.

To conclude, the phrase 'the Lord appeared to him' in Genesis 18 must be interpreted as a prolepsis that signals blessedness. Descriptions of terrified responses after the recognition of his deity are not necessary. The divine title 'the Lord' is used for the most privileged one to whom God reveals his blessed presence and when he speaks to his favoured one in person from the first moment of encounter (cf. Hamilton 1976:419; Sarna 1989b:112; Skinner 1980:278). Abraham was privileged to such an extent that he was allowed to speak to the Lord face to face (cf. Gn 15:2; Nm 12:8; Hamilton 1976:419; Sarna 1989b:112). Thus, the opening phrase, 'the Lord appeared to' demonstrates God's blessed favour for his intimate covenant partner (Gn 18:1), as opposed to a phrase such as 'the angel of the Lord appeared to'.

\section{THE TEST MOTIVE VIEW, AS BASED ON GREEK MYTHOLOGY}

In Greek mythology, the motif for a deity's visit is to test the hospitality of a host. Generally in the Old Testament, the 
anthropomorphic appearance of a divine being is done through 'a single angel of the Lord' (cf. Jos 5:13; Jdg 6:11; 13:3; 2 Sm 24:16; Bush 1981:282-283). But in the episode of Genesis 18, the Lord appeared in the form of three men, which is of exceptional significance in the Old Testament (cf. Von Rad 1972:205). Some scholars even assume that this is a reminiscent of pagan polytheism and therefore attempt to interpret the narrative using retribution theology (cf. Gunkel 1997:193-194; Simpson 1978:616; Skinner 1980:299; Wenham 1994:45). In Greek myths, the account of the birth of Orion was seen as the nearest parallel. This myth plays out as follows: Zeus, Poseidon and Hermes visit the childless Hyrieus in Boeotia. Hyrieus served them hospitably and they helped him acquire the son for which he had longed (cf. Gunkel 1997:192-193; Letellier 1995:200-201; Simpson 1978:616617; Skinner 1980:302-303; Ross 1988:338).

Hospitality is the only real virtue to be tested in pagan parallels (cf. Roop 1987:126; Von Rad 1972:205). So the purpose of the Lord's visit can be understood as a test of Abraham's faithfulness, in the fashion of Greek legends (cf. Gunkel 1997:193; Simpson 1978:616-617; Skinner 1980:299). Consequently, it is understood that the incognito visitors give a majestic reward because of the hospitality of the host (cf. Skinner 1980:302-303; Von Rad 1972:205; Wenham 1994:45).

There are, however, three reasons why we cannot use pagan theology to read the Hebrew narrative. Firstly, Greek parallels probably come from a much later period than the Abraham narrative and also from a different culture, so their connection must be quite indirect (cf. Ross 1988:341; Westermann 1985:276). If one accepts that being hospitable to visitors was taken for granted and was a common cultural duty in the ancient Near East, then, attention must be paid to other significant elements of the narrative (cf. Bush 1981:282; Exell 1900:1; Hamilton 1995:8; Von Rad 1972:206; Westermann 1985:276).

Secondly, the Greek style of narrating is widely different to that of Hebrew. Lundbom (1998) explains the differences between them comparatively as follows:

Greek epic style is essentially hypotactic ... descriptions are commonplace and in them much detail. Syntactic connection between narrative parts show clear results and remains nothing obscure ... Hebrew epic style is essentially paratactic, that is, a style typified by economy of detail ... Syntactic connections are few in number, which remain in obscurity. Feelings and thoughts of persons are not externalized, that is, motives are lacking and purposes remain unexpressed.

(Lundbom 1998:136-138)

Therefore, we rather attempt to divert our attention to the author's own theological view as expressed in the text, as well as to the common theological perspective found among biblical parallels in the Old Testament.

Thirdly, the retribution theology, which emphasises only the meritorious works of Abraham, collides with the systematic central themes of the whole Abraham narrative (Gn 12:1-25:11; cf. Hasel 1998:77, 92; Westermann 1985:276). The author's theological view, as expressed in the characterisation of God in the Abraham narrative, unilaterally emphasises God's grace in election, his giving of promises and his faithfulness to fulfil his promise for the covenant partners (cf. Mathews 1996:122; Tenney 1977). There is a great difference whether the promise of seed is a gift from the Lord or whether it is a reward for some hospitable manners (cf. Von Rad 1972:209; Westermann 1985:276).

Many scholars have been interpreting Abraham's act of invitation of the heavenly visitors as a good illustration of being hospitable for strangers, according to the perspective of Hebrews 13:2 in the New Testament (cf. Ambrose, Augustine; Brueggemann 1997:166; Calvin 1992:468; Exell 1900:1-5; Hamilton 1995b:9; Oden 2002:62-64; Wenham 1994:45). The result of this interpretation produces the same retribution theology, which is far from the Lord's faithfulness to fulfil what he promised.

\section{THE INTERPRETATIVE PERSPECTIVE OF HEBREWS 13:2}

The NIV translates the word of Hebrews 13:2 as: 'Do not forget to entertain strangers, for by so doing some people have entertained angels without knowing it'. Scholars simply took the Abraham and Lot narratives as the ideal examples of Christian hospitality. They also asserted that Abraham received Isaac as the reward of his hospitality (cf. Gunkel 1997:192-193; Simpson 1978:616). This theological interpretation has been widely used since the time of the Early Church Fathers (cf. Gunkel 1997:192; Hamilton 1995b:9; Jarick 2000:86; Oden 2002:64; Wenham 1994:45). Many Old Testament commentators also did not seem to have paid much attention to the author's own sophisticated interpretative perspective in the Fellowship Narrative (Gn 18:1-15). There are, however, some reasons why we should not use Hebrews 13:2 to understand the Fellowship Narrative.

Firstly, the interpretation is based on an improper English translation of the Greek words in Hebrews 13:2, $\tau \hat{\eta} \varsigma$ ф $\left\llcorner\lambda \circ \xi \in v^{\prime} \alpha \varsigma\right.$

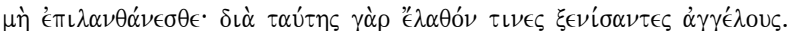
The various translations of the verse can be compared with each other in the following translations:

- KJV Hebrews 13:2, 'Be not forgetful to entertain (strangers), for thereby some have entertained angels unawares'.

- NIV Hebrews 13:2, 'Do not forget to entertain (strangers), for by so doing some people have entertained angels without knowing it'.

- YLT Hebrews 13:2, 'of the hospitality be not forgetful, for through this unawares certain did entertain messengers'.

The YLT's translation is nearly a literal translation. In the Greek text of Hebrews 13:2, there is no word for 'strangers'. Therefore, my own literal translation will be as follows: 'Do not forget to do hospitality, for thereby some have entertained angels (or messengers) without knowing it.' The object of receiving hospitality is not mentioned in the original text, but is rather to be decided by the context of the admonition in Hebrews 13:1-4.

The visitors in Genesis 18 are not 'strangers' (aliens) in the literal sense indicated above, but rather 'three men' who appeared suddenly at noontime (cf. Exell 1900:2; Gunkel 1997:192; Letellier 1995:80; Sarna 1989a:128; Simpson 1978:617; Skinner 1980:299; Westermann 1985:276). Each description used to indicate how Abraham welcomed the three men connotes that they are superior to Abraham, so that one can hardly imagine that he is showing a brotherly love for poor and weary ones (strangers or foreigners) (Gn 18:1-15; cf. Bush 1981:283).

The theme of being hospitable to strangers (or aliens) is found in the Old Testament:

The alien (ㄱ) living with you must be treated as one of your nativeborn. Love him as your self, for you were aliens in Egypt. I am the Lord your God.

(Lv 19:33-34)

The LXX translates the term пробฑं $\lambda$ utos (proselytos), which means 'proselyte' (a convert from pagan religion) instead of simply as xenos ( $\xi \in \nu \circ \xi ;$ alien) (Lv 19:34; cf. Milligan 1989:481).

Secondly, one of the main themes of the narrative complex of Genesis 18-19 is that the Lord had to punish the wicked because their 'outcry' reached him (cf. Gn 6-9; cf. Hartley 1995:177; Mathews 1996:208-215). The narrator clearly tells that 'he remembered Abraham, and he brought Lot out of the catastrophe (Gn 19:29)', which means that Lot was not delivered on his own merits (or his righteousness, or even because of his hospitality to two strangers) but through Abraham's intercession (cf. Wenham 1994:59). Lot's customary hospitality for strangers was not the essential reason for receiving salvation. According to nomadic customs showing hospitality towards visitors was taken for granted (cf. Westermann 1985:276).

Thirdly, the Hebrew writer's depiction: 'Have entertained angels without knowing' (Heb 13:2) squarely conflicts with 
the depiction of Abraham's keen act of 'observation and recognition' the Genesis narrator uses, particularly in terms of the formal vocabulary of prophetic experience, 'and he lift up

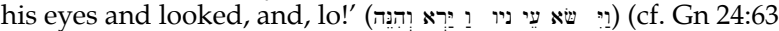
37:25; 43:29; Jdg 19:17; Ezk 1:4, 15, 26; 2:9; 8:2; 10:1, 9; Zch 5:5; Letellier 1995:81; Mathews 1996:216). The physical meaning of the verb har denotes the sense of perception with the eyes (cf. Van Gemeren 1997:1007-1014). Thus, the meaning of the Hebrew verb Qal of har ('to perceive', 'understand' and 'learn') contradicts the depiction of 'without knowing it' (cf. Gn 1:10, 12; Ex 3:4; 8:11; Botterweck 1974; Brown 1979; Harris 1980; Sarna 1989a:92)

The author's perspective in the Fellowship Narrative (Gn 18:1-15) should be seen within the context of the larger Hebron narrative (Gn 17-18:33). The episode at Hebron (Gn 17:7-18:33) shows a similar sequential plot structure as its parallel in Exodus 24:1-18.

\section{INTERTEXTUAL STUDY OF SEQUENTIAL}

\section{PLOTS FOUND IN THE HEBRON NARRATIVE}

\section{(GN 17:7-18:33) AND THE COVENANT} NARRATIVE IN EXODUS 24:1-18

During the earlier stage of God's calling of Moses, Moses only heard the words of the Lord (Ex 3:4-17; 6:1, 28; 7:1, 14, 19; 8:1, 16, 20; 9:1; 10:1; 11:1; 12:1; 13:1; 14:1; 16:4; 17:5). In Exodus 24, 'the gift' of eating a covenant meal in God's presence was presented to Moses and 70 elders, in the same way that Abraham had earlier experienced sharing a meal with the Lord (cf. Durham 1987:344-345; Ellison 1973:136; Henry 1712:380). Therefore, it seems to be very significant to compare the sequential plots of both covenantal events (Gn 17:7-18:33 and Ex 24:1-18). The rites to make a covenant were conducted in Exodus as follows:

- Firstly, covenant rites were made between the Lord and his people (Ex 24:3-8)

- Secondly, the gift of eating fellowship meals in God's presence is granted (Ex 24:9-11).

- Thirdly, Moses entered into the cloud of God's glory to receive the tablets of the Ten Commandment and stayed there for 40 days (Ex 24:12-18).

A similar sequence is found in the events at Hebron (Gn 17 and 18):

- Firstly, a covenant was made by performing circumcision on every male in Abraham's household (Gn 17:7-27).

- Secondly, eating the fellowship meals of the Lord is granted (all the household of Abraham is assumed to eat: Gn 18:1-8).

- Thirdly, Abraham received a word of reconfirmation. He walked along with the Lord and had an intimate dialogue with him concerning Sodom and Gomorrah (Gn 18:9-33).

What is significant here is that a fellowship meal follows immediately after the performing of covenant rites. Thus, the sequence of events at Abraham's camp is in agreement with those that occurred later at Mount Sinai, in regard to the covenant making and eating of meals (cf. Ross 1988:339). Here, I presume that the unwritten element in the fellowship meals at Abraham's camp is that all members of Abraham's household also participated in the meal at Abraham's table. For, according to the culture of the Near East, all of the household members usually enjoy the leftovers of the prepared food for the guests (cf. Bush 1981:288; Exell 1900:5; Ross 1988:343).

There is a significant comparative feature between historical narratives $(\mathrm{Jdg} 6 ; 13)$ and patriarchal narratives (i.e. those of Abraham and Moses). This is that the theophanic events in Judges 6 and 13 happened as the first experience of the judge in his lifetime, whereas, theophanic events in patriarchal narratives occurred at the pinnacle stage of their life, after they had already experienced God's revelations in various ways (Gn 18; Ex 24). Therefore, there are no depictions of the patriarch's terrified response to the theophany in the episodes of the patriarchal narratives (Gn 17:7-18:33; Ex 24:1-18). In the historical narratives of the judges (Jdg 6;14), however, the depictions of the scared and terrified responses of the covenant partners are vivid. This implies that the Lord grants Abraham and Moses the privilege of sharing intimate fellowship with him, compared to other covenant partners who only encountered God's presence for the first time in their life (cf. Buber 1982:39; Durham 1987:344-345; Ellison 1973:136; Sailhamer 1976:137).

The co-relationship between executing circumcision and consequently eating meals reminds me of another parallel of the anthropomorphic appearance of the deity in the book of Joshua 5 . I expect that some new key points in the following intertextual study would enhance a better understanding of the significance of the events at Hebron.

\section{INTERTEXTUAL STUDY BETWEEN GENESIS 18 AND JOSHUA 5 CONCERNING CIRCUMCISION AND THEOPHANY}

Both of these theophanic events occurred immediately before God executed justice over wicked cities (cf. Harris 1980; Speiser 1964:139). Both episodes report the same mass circumcision rites and the same anthropomorphic appearance of the Lord after the rites (cf. Henry 1708:27; Soggin 1972:70). Both narratives use the same phrase: 'and he lift up his eyes and looked, and, lo!' (וי שא עיניו וירירא ודיונה; Gn 18:2; Jos 5:13). Both episodes describe the divine men having the same 'firm standing' posture: 'stand' (נצב; Gn 18:2), 'stand' (עמד; Jos 5:13). Also, both covenant partners bowed down to the ground as they discerned the identity of the one who suddenly appeared to them. Therefore, it seems to be significant to research the structural co-relationship between mass circumcision and the Lord's visit by using intertextual study. To conduct this research on common terms and their theological nuances seems to be significant in this regard.

The narrative of Joshua 5:1-15 tells of three important historical incidents (mass circumcision, eating Passover and theophany) as being essential to Israel's identity. The episode narrated in Genesis 17:23-19:29 occurs in the following sequence:

- executing mass circumcision (Gn 17:23-27)

- theophany in human form to Abraham at the pinnacle of his devoted life (Gn 18:1-5)

- having fellowship meals, which is proleptic for Passover (Gn 18:6-8)

- God executed justice over wicked Sodom (giving salvation to Lot's family; Gn 19).

Similarly, the episode narrated in Joshua 5:2-6:27 occurs as follows:

- executing mass circumcision (Jos 5:2-9)

- celebrating the Passover (Jos 5:10)

- theophany in human form to Joshua for the first time in his devoted life (Jos 5:13-15)

- God's execution of justice on Jericho (giving salvation to Rahab's household; Jos 6:22-23).

Thus, both narratives (Gn 17-18 and Jos 5:1-15) show a similar plot structure (sequence of events) in similar contexts. The most significant feature of both narratives is that the divine visitor's appearance occurred right after the obedient performing of mass circumcision (cf. Jos 5:2-9; Henry 1708:27; Gn 17:23-27; Ross 1988:341; Sailhamer 1976:143; Sarna 1989a:128; Wenham 1994:41). The passage is generally understood by modern scholars as the work of the Deuteronomic historian, who considered circumcision as essential to becoming a member of God's covenant people (cf. Howard 1998:29). It can be assumed that the Deuteronomic historian added the passage in Joshua 5:4-7 to harmonise this tradition with the one of Abraham. The circumcision episodes are always illustrations of Israel's faithful obedience. Consequently, the appearance of the divine being must be interpreted as God's presence among his covenant partners in response to their obedience (cf. Henry 1708:27; Howard 1998:161). 
There are also many other similar descriptive elements that should be noticed in both narratives (Gn 17-18; Jos 5:1-15). To compare their theological nuances seems to be significant. Firstly, the phrase 'and he lift up his eyes and looked, and,

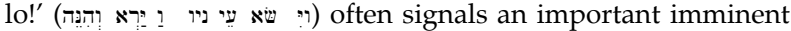
event (cf. Gn 24:63; 43:29; Jdg 19:17; Mathews 1996:216). The Hebrew verb Qal of ראה ('to look at'), however, belongs to the formal vocabulary of prophecy as well (cf. Botterweck 1974; Sarna 1989a:92). Therefore, the verb has the metaphorical meaning such as 'perceive', 'understand' and 'learn' (Gn 1:10, 12; Ex 3:4; 8:11; cf. Brown 1979; Harris 1980:823; Van Gemeren 1997:1007-1014). Thus, the word pair 'lift up his eyes and saw' is understood as the tautological expression for the process of prophetic keen 'observation and recognition' (cf. Gn 24:63; 37:25; 43:29; Jdg 19:17; Ezk 1:26; 8:2; Zch 5:5; Botterweck 1974; Letellier 1995:81; Mathews 1996:216). Such a nuance of the word pair implies that both Abraham and Joshua were favoured enough to recognise the identity of the divine ones appearing to them. This is the textual proof of Abraham's immediate recognition of the deity from the first moment.

Secondly, the divine men are depicted in the posture of 'firm standing' (נב (נצ) in both Abraham's episode (Gn 18:2) and Joshua's episode (cf. Brown 1979). Even though in Joshua's episode a different verb (עמד) for standing posture is used, the depiction of a divine man 'with drawn sword in his hand' apparently gives the same nuance of firm standing as in Genesis 18:2. Such depictions remind one of the ominous and authoritative standing of the angel of the Lord in Balaam's episode (Nm 22:31; cf. 2 Sm 24:16). Such an overwhelming and authoritative standing posture of deities might have caused Abraham and Joshua to bow down to the ground before them (Gn 18:8, 22; Jos 5:15; cf. Henry 1708:27). In its specific context the nuance of 'bow down' does not seem to be just civil respect but the act of worshipping the Lord (cf. Ex 20:5; 24:26; 2 Chr 7:3; Is 2:20; 44:15; 46:6; Brown 1979).

Thirdly, both narratives use the surprised exclamation of ('Lo!') but do not describe any terrified response to the divine being's appearance. Consequently, the purpose of the divine man's visit may be understood as something hopeful and blessed, as the opening phrase 'the Lord appeared to' denotes a well-wishing purpose (cf. Auld 1984:35; Henry 1708:27; Hamilton 1976:419; Howard 1998:161; Sarna 1989a:112; Skinner 1980:278). Abraham and Joshua are thus both honoured by the Lord's favourable appearance.

Similar motives in the plot structures of divine visits such as these, and many similar narrative terms used, provide us with a common interpretative perspective. The Lord graciously visits his beloved covenant partners who obeyed his command of circumcision. Therefore, this study comes to the conclusion that a test motif for the visit of the Lord is not relevant here.

\section{CONCLUSION}

Many interpretations see a structural relationship between the Fellowship Narrative (Gn 18:1-15) and the following Sodom episode (Gn 18:16-9:38). This interpretation of the episode in Genesis 18:1-15 focuses on the performance of Abraham's hospitality, considering it as a meritorious work to obtain the reward or salvation.

Many scholars interpret Abraham's invitation of his visitors in accordance with the perspective of Hebrews 13:2 in the New Testament. The results of this type of interpretation hint at retribution theology. According to this study, however, such an interpretation collides with the author's own theological view concerning righteousness and deliverance (Gn 15:6; 19:29; 21:1). The author's theological view unilaterally emphasises God's grace in election, his giving of promises and his faithfulness in fulfilling his promise for the covenant partners. There is a vast difference between the promise of seed as a gift from the Lord and being a reward for hospitable manners.
Many scholars presume that Abraham could not recognise the divinity of his visitors by reading Hebrews 13:2 ('have entertained angels without knowing') back into this narrative. Such a presumption squarely conflicts with the depiction of the narrator of Genesis. Abraham's act of 'observation and recognition' (evident in the phrase, 'and he lift up his eyes and looked, and, lo!'; cf. Gn 24:63; 37:25; 43:29; Jdg 19:17; Ezk $1: 4,15,26 ; 2: 9 ; 8: 2 ; 10: 1,9 ;$ Zch 5:5), understood in terms of the formal vocabulary of prophecy, indicates otherwise. Both the physical and the prophetical meanings of the Hebrew Qal of ראה mean attentive 'seeing', with the nuance of 'to perceive', or 'understand'. These meanings contradict the depiction of 'without knowing it' The depiction of Abraham 'seeing' attests to Abraham's immediate recognition of the deity from the first moment. This is the author's interpretative perspective as presented in the Fellowship Narrative.

The structure of the first section (Gn 18:1-15) is closely linked with the preceding episode (Gn 17:23-27) via the syntactical function

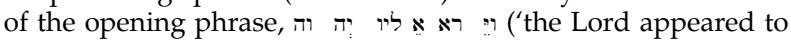
him'; cf. LXE, KJV; Gn 18:1a). Syntactically, the antecedent of 'he' is Abraham as referred to in Genesis 17:26, where Abraham obediently performed circumcision (Gn 17:23-27). This linking structure indicates that readers are to understand the events of the first section in light of the preceding events, as the author clearly indicates syntactically (cf. Gn 15:1).

Both episodes of Genesis 18 and that of Joshua 5 report the same mass circumcision rites and the same anthropomorphic appearance of the Lord after the rites. Many similar narrative elements occur in both narratives. These include: the phrase 'and

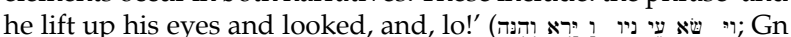
18:2; Jos 5:13) and the same 'authoritative firm standing' posture - 'stand' (נצ'; Gn 18:2), 'stand' (עמד Jos 5:13) - which caused Abraham and Joshua to bow down to the ground (Gn 18:8, 22; Jos 5:15). The most significant feature found in both narratives is that the divine visitor's appearance occurred right after the obedient performing of mass circumcision (cf. Gn 17:23-27; Jos 5:2-9). The circumcision episodes are always illustrations of Israel's faithful obedience. Consequently, the appearance of the divine being must be interpreted as God's favouring presence among his covenant partners in response to their obedience.

Another significant issue here is that special meals were consumed immediately after the mass circumcision (extraordinary meal in Gn 18:5-8; the Passover meal in Jos 5:10-11; cf. fellowship meals in Ex 24:11). The test-motif visit of the Lord is not relevant with any of these mutual interpretative perspectives indicated above in the parallels.

Within the larger context, the opening phrase 'the Lord appeared to' signals that the Lord appears to covenant partners with a promise of both land and descendants (Gn 12:7; 17:1-8; 26:2-4; 35:9-13). It signals the Lord's intimacy with his beloved ones as well. Therefore, no description of a terrified response after the recognition of the deity is found. In the Fellowship Narrative, started by the opening phrase, 'the Lord appeared to', the Lord grants Abraham the ability to participate as a privileged prophet in divine council like a friend (Gn 18:16-33; cf. 2 Chr 20:7). All of these elements attest to the benevolent purpose of the visit of the Lord.

In the Fellowship Narrative, the annunciation of the birth of Isaac is not accompanied by an indication of the fulfilment of the promise. This is located later in Genesis 21:1-7. Structurally, two perilous events (Gn 18:16-20:18) are sandwiched between the heading (Gn 18:1-15) and the closing part (Gn 21:1-7). The main theological theme of the sandwiched structure is that the chosen ones may face the threat of failing God's promise, but the Lord intervenes in these situations and fulfils his promise. Even though God's chosen ones show human deficiencies and weaknesses, Yahweh still rescues them and fulfils his promises (cf. Gn 12:1-13:2; 41; Ex 12:4). 
This sandwiched structure apparently shows that Abraham could not attain security by his own performance. Only God saves under such circumstances (cf. Dt 9:4-6). Therefore, the meritorious view that Abraham's hospitality earned him his son Isaac is not in line with the author's theological intent as shown by this sandwiched structure.

\section{REFERENCES}

Auld, A.G., 1984, Joshua, Judges, and Ruth, The Westminster Press, Philadelphia.

Block, D.I., 1999, The new American commentary, vol. 6, Judges, Broadman \& Holman, Nashville.

Boice, J.M., 1985, An expositional commentary, vol. 2, Genesis 12:136, 43, Zondervan, Grand Rapids.

Wikipedia, 2009, Book of Genesis, viewed 10 June 2009, from http://en.wikipedia.org/wiki/Book_of_Genesis

Botterweck, G.J., 1974, Sub verbo ראה, Theological dictionary of the Old Testament, William B. Eerdmans Publishing, Grand Rapids.

Brown, F., 1979, Sub verbo ראה, Hebrew and English Lexicon, Clarendon, Oxford.

Brueggemann, W., 1982, Genesis, interpretation: A Bible commentary for teaching and preaching, ed. J.L. Mays, John Knox Press, Atlanta.

Brueggemann, W., 1997, Theology of the Old Testament: Testimony, dispute, advocacy, Fortress, Augsburg.

Bush, G., 1981, Notes on Genesis, Klock \& Klock Christian Publishers, Minneapolis.

Bush, G., 1993, Commentary on Exodus, Kregel Publication, Grand Rapids.

Calvin, J., 1963, The Epistle of Paul the Apostle to the Hebrews and the First and Second Epistles of ST Peter, transl. W. B. Johnston, William B. Eerdmans Publishing, Grand Rapids.

Calvin, J., 1992, Genesis, transl. J. King, The Banner of Truth Trust, Carlisle.

Cassuto, U., 1964, A commentary on the Book of Genesis, The Magnes Press, Jerusalem.

Coats, G.W., 1983, Genesis with an introduction to narrative literature, William B. Eerdmans Publishing, Grand Rapids.

Driver, S.R., 1904, The Book of Genesis: With introduction and notes, Methuen \& Co., London.

Durham, J.I., 1987, Exodus, word biblical commentary, ed. D.A. Hubbard, , Word Books, Waco.

Ellison, H.L., 1973, Exodus, The Westminster Press, Philadelphia

Exell, J.S., 1900, The biblical illustrator: Genesis, Baker Book House, Grand Rapids.

Gunkel, H., 1994, The stories of Genesis, transl. J.J. Schullion, Bibal Press, Vallejo.

Gunkel, H., 1997, Genesis, transl. M.E. Biddle, Mercer University Press, Macon

Hartley, J.E., 1995, New international biblical commentary: Genesis, Hendrickson Publishers, Peabody.

Hartley, J.E., 2000, New international biblical commentary: Genesis, Hendrickson Publishers, Peabody.

Hamilton, V.P., 1976, The book of Genesis: Chapters 18-50, New international commentary on the Old Testament, William B. Eerdmans Publishing, Grand Rapids.

Hamilton, V.P., 1990, The book of Genesis Chapters 1-17: New international commentary on the Old Testament, William B. Eerdmans Publishing, Grand Rapids.

Hamilton, V.P., 1995a, The book of Genesis: Chapters 12-17, New international commentary on the Old Testament, William B. Eerdmans Publishing, Grand Rapids.

Hamilton, V.P., 1995b, The book of Genesis: Chapters 18-50, New international commentary on the Old Testament, William B. Eerdmans Publishing, Grand Rapids.

Harris, R.L., 1980, Theological dictionary of the Old Testament, Thomas Nelson Publishers, Nashville.

Hartly, J., 1988, Book of Job, New international commentary on the Old Testament, William B. Eerdmans Publishing, Grand Rapids.

Hasel, G., 1998, Old Testament theology: Basic issues in the current debate, William B. Eerdmans Publishing, Grand Rapids.
Henry, M., 1708, Mathew Henry's commentary, vol. II, Fleming H. Revell Co., Old Tapen.

Henry, M., 1712, Mathew Henry's commentary, vol. II, Fleming H. Revell Co., Old Tapen.

Howard, D.M., 1998, Joshua, Broadman \& Holman Publisher Nashville.

Jamieson, R., 2009, Commentary on Genesis 18, Commentary critical and explanatory on the whole Bible, viewed 10 April 2009, from http://www.biblestudytool.net/commentaries/ JamiesonFaussetBrown/

Jarick, J., 2000, Genesis, Sheffield Academic Press, Sheffield.

Keil, C.F. \& Delitzsch, F., 1996, The Pentateuch, Commentary on the Old Testament, vol. 1, Hendrickson, Peabody.

Knight, D.A., 2004, Methods of biblical interpretation, Abingdon Press, Nashville.

Letellier, R.I., 1995, Day in Mamre, night in Sodom: Abraham and Lot in Genesis 18 and 19, E.J. Brill, Leiden.

Lundbom, J.R., 1998, 'Parataxis, rhetorical structure, and the dialogue over Sodom in Genesis 18', in P.R. Davies and D.J.A. Clines (eds.), The world of Genesis: Persons, places, perspectives, Journal for the Study of the Old Testament, suppl. ser. 257, Continuum International Publishing Group, London.

Mathews, K.A., 1996, The American commentary, vol. 1b, Genesis 4:27-11:26, ed. E.R. Clendenen, Broadman \& Holman, Nashville.

Milligan, R., 1989, A commentary on the Epistle to the Hebrews, Gospel Advocate Company, Nashville.

Oden, T.C., 2002, Ancient Christian commentary on Scripture. Old Testament II: Genesis 12-50, InterVarsity Press, Downers Grove.

Roop, E.F., 1987, Believers church Bible commentary: Genesis, Herald Press, Scottdale.

Ross, A.P., 1988, Creation and blessing, Baker Book, Grand Rapids.

Sailhamer, J. H., 1976, Expositor's Bible commentary, vol. 2, Genesis, Zondervan, Grand Rapids.

Sailhamer, J.H., 1990, Expositor's bible commentary, vol. 2, Genesis, Zondervan, Grand Rapids.

Sailhamer, J.H., 1992, The Pentateuch as narrative, Zondervan Grand Rapids.

Sarna, N.M., 1989a, Genesis: The JPS Torah commentary, The Jewish Publication Society, Jerusalem.

Sarna, N.M., 1989b, Exodus: The JPS Torah commentary, The Jewish Publication Society, Jerusalem.

Simpson, C.A., 1978, The interpreter's Bible, vol. 1, Genesis, ed G.A. Buttrick, Abingdon, Nashville.

Skinner, J., 1980, The international critical commentary, vol. 1, Genesis, T \& T. Clark, Edinburgh.

Soggin, J.A., 1972, Joshua: A commentary, SCM Press, London.

Speiser, E.A., 1964, Genesis, The anchor Bible, Doubleday, New York.

Tenney, M.C., 1977, The Zondervan pictorial encyclopedia of the Bible, Zondervan, Grand Rapids.

Van Gemeren, W., 1997, New international dictionary of Old Testament theology and exegesis, vol. 1, Zondervan, Grand Rapids.

Venter, P.M., 2005, 'Narrative literature', unpublished lecture notes, University of Pretoria, Pretoria.

Von Rad, G., 1972, Genesis, SCM Press, London.

Wenham, G.J., 1987, Word biblical commentary, vol. 1, Genesis 1-15, ed. D.A. Hubbard, Word Books, Waco.

Wenham, G.J., 1994, Word biblical commentary, vol. 2, Genesis 16 50, ed. D.A. Hubbard, Word Books, Waco.

Westermann, C., 1985, Genesis 12-36: A commentary, transl. J.J. Scullion, Augsburg Publishing House, Minneapolis.

\section{Translations}

LXE - LXX English Translation

KJV - King James Version

NIV - New International Version

NIB - New International Version (BR)

YLT - Young's Literal Translation 